\title{
Discursos impressos de um padre político: análise da breve trajetória d' O Pregoeiro Constitucional
}

Printed Speeches of a Political

Priest: a Brief Analyses of the "O

Pregoeiro Constitucional"

\section{Françoise Jean de Oliveira \\ Souza}

Doutoranda em História pela

Universidade do Estado do Rio de Janeiro.

\begin{abstract}
Resumo
0 presente texto realiza uma análise da trajetória do periódico 0 Pregoeiro Constitucional, publicado pelo deputado e padre José Bento Ferreira Leite de Mello, em Pouso Alegre, visando atingir dois objetivos bem claros. 0 primeiro deles é o de perceber como este padre político discutiu os importantes acontecimentos que precederam à abdicação de Dom Pedro I, tomando a imprensa como principal instrumento de vigilância das ações do poder executivo e como tribuna para defesa de projetos de caráter liberal moderado. 0 estudo das proposições federalistas e constitucionais apresentadas por José Bento, bem como da maneira como estas ganharam novos significados num curto período de tempo, leva-nos, por sua vez, ao nosso segundo e mais amplo objetivo que é o de compreender a presença e as implicações do fenômeno de reconfiguração e deslocamento semântico dos conceitos e vocabulários políticos ocorrido nas primeiras décadas do século XIX brasileiro.
\end{abstract}

\begin{abstract}
The present text analyses the "O Pregoeiro Constitucional", published by the priest and member of the Parliament José Ferreira Leite de Mello, in Pouso Alegre. First of all, I try to unfold how this political priest discussed the important events that preceded the resignation of Dom Pedro I, as he used the press as his main tool to survey the actions of the Executive Power and also as tribune to stand for moderate liberal projects. The study of the federalist and constitutional proposals made by José Bento, which gained new meanings in a short period of time, lead me to my second and broader goal: the understanding of the reasons and implications behind the transformation of political concepts and vocabularies that occurred in the first decades of the 19th century.
\end{abstract}

\section{Palavras-chave}

Império do Brasil, imprensa, religião, vocabulário político, Estado / formas de governo

\section{Keywords}

Brazilian Empire, press, religion, political vocabulary, State / forms of government 
COSTA FILHO, Miguel. Imprensa Mineira no Primeiro Reinado. Rio de Janeiro: Brochura, 1955.

Assim chamada por ter como principais articuladores os padres Feijó, José Bento e Custódio Dias. Consistiu na tentativa de transformar a Assembléia Legislativa em Assembléia Constituinte para a aprovação da Constituição de Pouso Alegre. O Pregoeiro Constitucional, n. 56, p.231, 06 de abril de 1831.

Ibidem.

\section{1-0 padre, o político e o jornal.}

Os anos finais do governo de Dom Pedro I marcaram sobremaneira a vida cotidiana da Corte. Nestes tempos de batalhas políticas, surgiram novos espaços de sociabilidade, tais como a maçonaria e os clubes associativos e patrióticos que, em concomitância com a atuação da imprensa, indicavam a emergência de uma consciência política nova, manifestada através de formas de participação e de ação pública que extrapolavam as instâncias oficiais de poder. Vislumbra-se, naquela ocasião, a gestação do que poderíamos chamar de uma verdadeira esfera pública.

Em outro canto do país, perdido na vastidão do sul de Minas Gerais, o pequeno Arraial de Mandu também haveria de testemunhar importantes transformações. Por intermédio do ex-vigário local, o Padre José Bento Leite Ferreira de Mello, o Arraial foi elevado à categoria de Vila em 13 de outubro de 1831, passando a chamar-se Vila de Pouso Alegre. Também, sob a égide de José Bento, Pouso Alegre vivenciaria um grande melhoramento que, para aqueles tempos, caracterizava a possibilidade real de ligação entre os turbulentos acontecimentos da Corte e a pacata rotina da vila. Trata-se da criação do periódico 0 Pregoeiro Constitucional, de propriedade de José Bento. Tendo sido publicado pela primeira vez em 7 de setembro de 1830, 0 Pregoeiro Constitucional foi o primeiro jornal a ser lançado no sul de minas e o sexto da província'. Considerando as dificuldades da época, não só de publicar um jornal, mas deste também possuir uma tipografia própria, a aquisição de José Bento apresenta-se, sem dúvida, como um acontecimento de suma importância para aquela região. Vale lembrar que foi graças à tipografia d'O Pregoeiro, por ocasião do frustrado golpe de 30 de julho de 1832, que a até então desconhecida vila tornou-se comentada em outras províncias. Foi na oficina d'O Pregoeiro que se deu a edição do projeto de reforma da Constituição do Império, conhecido como "Constituição de Pouso Alegre" que seria implementada caso a "Revolução dos Três Padres"2 tivesse obtido êxito.

A presença de um jornal como $O$ Pregoeiro em uma vila como a de Pouso Alegre não pode, entretanto, ser entendida apenas como conseqüência da ação individual de José Bento. Para além da notável capacidade de realização desse padre, a existência d'O Pregoeiro reflete o anseio dos moradores daquela vila por novos canais de atuação política e o desejo de também participar, ainda que indiretamente, dos debates acerca do decadente governo de Sua Majestade Imperial. Se não havia ali, como ocorria na Corte, a existência de uma verdadeira esfera pública, não se pode negar que esta última dava os primeiros passos rumo ao sul da província mineira. 0 desejo associativo desses mineiros e, portanto, de participação política mostra-se claro quando observamos, por exemplo, que em 2 de abril de 1831 ocorre a instalação, em Pouso Alegre, da Sociedade Defensora da Liberdade e da Independência Nacional 3 , instalação esta ocorrida apenas quatro dias depois de sua criação oficial em São Paulo (29 de março de 1831) e 38 dias antes de seu estabelecimento na cidade do Rio de Janeiro (10 de maio de 1831). Na ocasião da implantação da Sociedade Defensora em Pouso Alegre, ela já contava com 108 sócios "soldados da pátria"4. Importante, contudo, atermo-nos um pouco à figura de José Bento. Vigário de Pouso Alegre desde 1811, ele tornou-se a figura central da região e um dos grandes responsáveis pelo seu desenvolvimento. Em 1821, foi membro do Conselho Geral da Província de Minas Gerais. Em seguida, foi 
0 presente texto faz parte da pesquisa de doutorado em desenvolvimento intitulada "Religião e Política no Primeiro Reinado e Regências: a atuação dos padres politicos no contexto de formação do Estado imperial brasileiro".
Destaca-se que esta divisão não tem por referência a formação partidária ocorrida em fins do periodo regencial. Por católicos liberais entendemos aqueles padres que, movendo-se na órbita da tradição ilustrada portuguesa, tinham uma idéia bastante moderna das liberdades da Igreja brasileira em face da Igreja universal, sustentando a legitimidade da interferência do poder civil para examinar os assuntos constantes nas bulas. Quanto aos católicos conservadores, tomamos por referência aquele grupo de clérigos que se caracterizavam pela defesa do ultramontanismo, na linha da centralização papal.

Para a elaboração deste trabalho foram lidos todos os 72 exemplares d'O Pregoeiro Constitucional cuja publicação se dava duas vezes por semana (quartas feiras e sábados), de 7 setembro de 1830 a 4 de junho de 1831.

Ver: BASILE, Marcello Otávio Néri Campos. Anarquistas, Rusguentos e Demagogos: os liberais exaltados e a formação de uma esfera pública na corte imperial (1829-1834). 2000. 366f. Dissertação (Mestrado). Universidade Federal do Rio de Janeiro, Rio de Janeiro, 2000; MOREL, Marco. As Transformações dos Espaços Públicos. Imprensa, Atores Políticos e Sociabilidades na Cidade Imperial. (1820-1840). São Paulo: HUCITEC, 2005; NEVES, Lúcia Bastos Pereira das. Corcundas e Constitucionais: a cultura politica da independência (1820-1822). Rio de janeiro: Revan/FAPERJ, 2003.

SKINNER, Quentin. As Fundações do pensamento politico Moderno. São Paulo: Companhia das letras, 1996; __________. Liberdade antes do Liberalismo. São Paulo: Editora UNESP, 1999; POCOCK, J.A. O conceito de linguagem e o Métier D'Historien: Algumas considerações sobre a prática. _-______._. Linguagens do Ideário Político. ( trad.) São Paulo: EDUSP, 2003.

\section{0}

KOSELLECK, Reinhart. Uma História dos Conceitos: problemas teóricos e práticos. Estudos Históricos, Rio de Janeiro, vol. 5, n. 10, 1992 deputado geral em três legislaturas - 1826 a 1834 - e, finalmente, senador do Império em 1834. Também participou ativamente da tentativa de golpe realizada em 1832, bem como do golpe da Maioridade e da Revolução de 1842. Trata-se, sem sombra de dúvida, de um tipo muito comum nas duas décadas primeiras do Império brasileiro e que convencionamos chamar de padre político 5 .

Quanto à questão dos padres políticos como um tipo particular de categorização, vale uma ressalva. Em nenhum momento do Primeiro Reinado ou das Regências, os padres políticos conseguiram organizar-se como um grupo monolítico. Na verdade, o clero brasileiro divergia entre si, tanto no que dizia respeito ao modelo político a ser adotado no Brasil, quanto às reformas referentes à situação da Igreja em face do Estado. Sem pretender esgotar em esquemas fechados toda a variedade de posicionamentos existentes no interior do clero, pôde-se perceber que, grosso modo, este se encontrava dividido entre dois grupos ou duas tendências politico-religiosas não organizadas oficialmente e que, para facilitar o estudo, optamos por chamar de "católicos liberais" e de "católicos conservadores". Estes grupos teriam em padre Diogo Feijó e em Dom Romualdo Antônio de Seixas, arcebispo da Bahia, suas respectivas lideranças ${ }^{6}$. José Bento, pela sua trajetória político-religiosa pode ser identificado como membro do grupo liberal, ou, como diziam seus detratores conservadores, como um "feijoísta".

O Pregoeiro Constitucional foi criado por José Bento com o principal intuito de discutir o governo de Dom Pedro I que, em 1830, encontrava-se profundamente abalado pelas críticas que punham em cheque a sua constitucionalidade. Acompanhando os acontecimentos políticos que precederam a abdicação do imperador, bem como se posicionando frente a estes, 0 Pregoeiro permitiu aos mineiros, ainda que sob a perspectiva particular de José Bento, acompanhar mais de perto o desenrolar das disputas travadas na Corte. Deste modo, a leitura deste jornal ${ }^{7}$ apresenta-se como uma forma de acessar as propostas defendidas pelo padre mineiro, bem como o sentido e a amplitude dos conceitos por ele utilizados, contribuindo para um melhor conhecimento das tendências políticas daqueles que compunham o grupo dos católicos liberais. Guardamos, contudo, o cuidado de não realizar uma associação automática entre as propostas de José Bento e o perfil político de toda a coletividade do clero liberal. Estudos individuais como o aqui realizado com o vigário de Pouso Alegre servem tanto para demonstrar comportamentos coletivos e freqüentes, como para revelar as irredutibilidades dos individuos.

Resta lembrar que um estudo que se propõe a analisar os discursos políticos enunciados na primeira metade do século XIX deve estar atento a um fenômeno muito característico deste contexto histórico, embora não restrito a ele. Trata-se da rápida reformulação dos conceitos e dos vocabulários políticos disponíveis para os embates então realizados. Trabalhos recentes sobre o Império brasileiro chamam-nos a atenção para a presença e as implicações do fenômeno de reconfiguração e deslocamentos semânticos dos conceitos ocorrido nas primeiras décadas do século XIX brasileiro ${ }^{8}$.

Diante deste alerta, destacamos a importância para o presente estudo das indicações teórico-metodológicas de Jonh Pocock e Quentin Skinner9, bem como da perspectiva metodológica da história conceitual desenvolvida por Reinhart Koselleck10. Estes autores possuem em comum a percepção de que os conceitos não devem ser tratados como atemporais e imutáveis, mas 
11

Em 6 de maio de 1826, D. Pedro I abriu a primeira Assembléia Geral do Brasil já com atitudes e discursos que confirmavam a autoridade suprema de seu poder. Deste modo, iniciados os trabalhos legislativos, a Câmara, apoiada pela imprensa, passou a medir forças com o Executivo e seus poderes arbitrários.

12

O Pregoeiro Constitucional. N. 1, p.1, 7 de setembro de 1830.

13

Ibidem.

14

Ibidem.

15

Ibidem.

16

O Pregoeiro Constitucional, N.10, p 40, 9 de outubro de 1830.

17

MOREL, Marco. As Transformações dos Espaços Públicos. Imprensa, Atores Políticos e Sociabilidades na Cidade Imperial. (1820-1840) São Paulo: HUCITEC, 2005. que, ao contrário, possuem uma historicidade revelada a partir da relação estabelecida entre as linguagens políticas em uso, o contexto de sua enunciação e os atores políticos que a expressavam. Conseqüentemente, estudos pautados na análise de ideários políticos, tal como o aqui proposto, devem guardar o cuidado de perceber as transformações pelas quais os conceitos e linguagens passavam, de modo a não lhes atribuir sentidos que, pelo contexto em questão, não seriam capazes de conter, ou, por outro lado, não perceber os novos sentidos que foram atribuídos às velhas linguagens.

\section{2- 0 pregoeiro do sistema constitucional.}

A crise política estabelecida entre o poder legislativo e o imperador, já com o início das atividades da Assembléia Geral em 1826 e, acirrada a partir de 183011, fez com que José Bento tomasse a imprensa como uma das suas principais armas de combate ao espectro do absolutismo. Nas primeiras edições d'O Pregoeiro Constitucional, o editor apresenta aquela que seria a sua maior bandeira de luta: a defesa do sistema constitucional. Segundo conta José Bento, ao ver a Constituição ameaçada por uma classe de "ineptos cidadãos" - classe esta que receberá várias denominações ao longo das edições, tais como portugueses, corcundas, absolutistas e recolonizadores - ele, "convencido da rigorosa obrigação que tem todo cidadão de concorrer para a pública felicidade12" sai em defesa do que chama de "bela", "nobre"e "lisonjeira"situação política:

\section{É, porém preciso, por dever, por honra e até por um justo interesse manter esta mesma dignidade, sustentar esses direitos, conservar esta posição e fazer efetiva esta responsabilidade; mas como o faremos nós? Sustentando, e só sustentando a Constituição ${ }^{13}$.}

A defesa do sistema constitucional passava, por sua vez, pela constante vigilância das ações do poder Executivo. Este, escreve José Bento, "ocupará não menos nossa atenção e seremos a seu respeito tão pródigos em render-lhe todo louvor, quanto severos em censurar seus passos tortuosos", "14sendo que, mais adiante, ele alerta os seus co-provincianos para os riscos de um "despotismo disfarçado".

E interessante observar o papel de destaque dado à imprensa pelo editor d'O Pregoeiro nessa luta contra os inimigos da Constituição brasileira. A imprensa seria nada menos do que "o garante (SIC) mais firme da nossa e de toda a Constituição política, ela é o penhor mais seguro da nossa liberdade (...) é a armadura inexpugnável com que nos defendemos dos golpes do despotismo". ${ }^{15}$ Ressalta-se, contudo, que o poder e a legitimidade da imprensa viria do fato dela ser apresentada como representante maior da opinião pública, assim como o instrumento capaz de submeter os administradores da nação ao "Tribunal da pública opinião". É com êxtase que José Bento anuncia que:

Os periódicos liberais têm-se multiplicado consideravelmente em relação ao Estado de nossas luzes: eles formarão a opinião pública e lhe darão a força necessária para conseguirmos completa vitória sobre o absolutismo. ${ }^{16}$

Morel17 lembra-nos que opinião pública remete a uma expressão que desempenhou papel de destaque na constituição dos espaços públicos e de uma nova legitimidade nas sociedades ocidentais a partir de meados do século XVIII, refletindo o desenvolvimento de uma consciência política na 
18

O Pregoeiro Constitucional, N.10, p. 40, 9 de outubro de 1830.

19

O Pregoeiro Constitucional. N.12, p 49, 16 de outubro de 1830.

20

O Pregoeiro Constitucional. N.24, p 98, 27 de novembro de 1830.

21

FONSECA, Silvia Carla Pereira de Brito. A Idéia de República no Império do Brasil: Rio de Janeiro e Pernambuco (1824-1834). 2004. Tese (Doutorado). Instituto de Filosofia e Ciências Sociais, Universidade Federal do Rio de Janeiro, Rio de Janeiro, 2004.

22

O Pregoeiro Constitucional, N.2, p.1, 11 de setembro de 1830.

23

O Pregoeiro Constitucional.N.3, p.12, 15 de setembro de 1830.

24

O Pregoeiro Constitucional, N.12, p.48, 16 de outubro de 1830.

25

MATTEUCCI, Nicola. Contratualismo. IN: BOBBIO, Noberto et alii. Dicionário de Politica. 10 ed. Brasilia/ DF: Universidade de Brasilia,1997. Vol. 1. esfera pública. 0 conceito de opinião pública, todavia, assumiu dois significados no contexto histórico brasileiro aqui analisado. Um primeiro, mais abstrato, a vê como o reinado da sabedoria, da prudência e da razão, que se contrapõe à exaltação política, às revoluções e transformações bruscas da ordem. 0 segundo significado identifica a opinião pública com a vontade legítima da maioria que se reuniria para decidir o bem comum. Não se trata neste caso, ao contrário da primeira concepção, de uma soberania da razão, e, sim, da vontade expressa pela maioria e que atuaria como um verdadeiro tribunal. Muito comum também, era a utilização híbrida e até contraditória das diferentes concepções de opinião pública por um mesmo periódico e, até, em um mesmo artigo.

Buscando aproximar-se da segunda concepção acima apresentada é que o nosso padre redator afirma ser a opinião pública - aqui reificada e tomada como um sujeito político - "a base dos governos representativ os", 18 devendo o soberano"mais do que tudo render-se a opinião pública como principal e único assento de sua autoridade".19 Uma vez entendido que a imprensa livre consistia no instrumento primeiro de manifestação da opinião pública, ela atuaria, portanto, como "a salva guarda de nossos direitos políticos e civis". 20 Entretanto, como veremos mais adiante quando tratarmos da noção de povo neste jornal, é possivel acreditar que essa idéia de "maioria" subjacente à noção de opinião pública não queria dizer, de fato, que o nosso editor assumia um discurso igualitário, baseado na soberania do povo. Trata-se, na verdade, de recorrer à imagem da opinião pública para legitimar os projetos políticos defendidos pelo periódico a partir de uma operação simbólica que transforma opiniões individuais ou setoriais em opinião geral.

Compreendidos os meios pelos quais José Bento dizia ser possivel defender o sistema constitucional brasileiro, resta analisar com mais vagar como ele entendia o conceito de Constituição, visto que, naqueles dias de rápidos deslocamentos semânticos, a idéia de Constituição poderia indicar simplesmente a ordem constituída, relacionada a instituições fundadas na tradição ${ }^{21}$. Busquemos a resposta, portanto, nas palavras do nosso padrepolítico:

\footnotetext{
Analise-se, entretanto que mistério encerra em si a palavra Constituição e porque motivo conta tamanho número de antagonistas, erro este que será fácil inferir-se da sua simples definição: ela não é senão o despotismo das Leis, que garantem a nossa vida, liberdade e propriedades; ou como dizem outros, a Constituição não é senão a declaração expressa do modo porque um povo quer ser governado 22 .
}

Parece claro que a Constituição é aqui entendida como a expressão do pacto social. A palavra Constituição, inclusive, é substituída várias vezes pelo termo "Pacto Fundamental".23Também, José Bento escreve que "todos os deveres de um soberano trazem a sua origem da convenção pela qual um povo the tem confiado o exercicio de sua soberania".24 Não obstante a diversidade das formulações que compõem as teorias contratualistas, podese observar que o editor d'O Pregoeiro adota a premissa comum aos autores dessa escola que defendem que o princípio de legitimação das sociedades políticas é exclusivamente o consenso. Este consenso, por sua vez, decorre do contrato, expresso ou tácito, firmado pelos homens entre si, no sentido de conceder a uma das partes, ou a uma assembléia, a capacidade de fazer leis, assinalando, com isto, o fim do estado natural e o início do estado social25. 
26

O Pregoeiro Constitucional. N.68, p. 281, 18 de maio de 1831.

27

FASSO, Gido. Jusnaturalismo. In: BOBBIO, Noberto et alii. Dicionário de Política. 10 ed. Brasilia/DF: Universidade de Brasilia, 1997. Vol. 1.

28

No Brasil, o liberalismo assumido por parte significativa do clero, recebeu uma coloração cristã. Isto, teve como conseqüência a possibilidade de se unir a convicção religiosa a atitudes revolucionárias. Ver: AZZI, Riolando. A Crise da Cristandade e o Projeto Liberal. Historia do pensamento católico no Brasil - II. São Paulo: Edições Paulinas, 1991.

\section{9}

Dentro da tradição retórica brasileira, o argumento de autoridade era um requisito indispensável de convencimento. Ver: CARVALHO, José Murilo de. História Intelectual no Brasil: a retórica como chave de leitura. Topoi. Revista de História. Rio de Janeiro: 7 Letras, N. 1. p. 123152,2000
Com o intuito de demonstrar a origem contratual do governo de Dom Pedro I, José Bento lança mão de fundamentos jusnaturalistas. A peculiaridade da argumentação construída pelo padre político, todavia, justifica aqui uma citação mais extensa.

0 homem nasceu livre, independente e imortal, ele deve respeitar em si e nos seus semelhantes à imagem da divindade que o encheu de benefícios e ninguém, seja quem for, pode jamais ter o direito de aviltar a sua dignidade.Anteriormente a todos os legisladores humanos, quis tão bem Deus dar a sua criatura Leis que afiançassem a sua vida, direitos e preeminência: 0 onipotente é o autor da lei natural, dessa lei assim denominada porque ela propende para proteger as prerrogativas naturais do homem porque é anterior a todos os pactos sociais e a todas as instituições politicas. (....) Perante esta lei, bem como em presença do Ente Supremo que a ditou, todos os homens são iguais, todos os irmão e membros da mesma família, ninguém se acha autorizado para quebrar os laços dessa fraternidade. Deus e a natureza deram poder unicamente aos pais, relativamente a quem Ihes deve a existência; a autoridade paternal é a mais antiga e amais sagrada que subsiste entre os homens. (...) Os filósofos de todas as eras concordam nesta verdade incontestável e confessam que anteriormente a todos os estabelecimentos humanos os homens deveram reconhecer um legislador supremo e uma lei natural. Se, pois é constante que desde o princípio do mundo e por espaço de muitos séculos não houve grandes sociedades, nações, monarcas nem tiranos é constante também que estas instituições foram obras de homens. 26

Na passagem acima, José Bento sustenta a premissa jusnaturalista de que existe um conjunto de direitos que, inerentes ao ser humano e anteriores à constituição da comunidade política, seriam naturais e, portanto, ensejariam o Estado como um produto da vontade racional. Desnaturalizando o Estado, isto é, tomando-o como artificialmente construído, o editor d'O Pregoeiro afasta qualquer possibilidade de perceber no governo de Dom Pedro I alguma sustentação divina que legitime o seu abuso de autoridade. Destarte, aponta a obediência dos filhos para com o pai como sendo um direito anterior ao direito positivo, herança do pensamento jurídico romano que permanece no pensamento jusnaturalista ${ }^{27}$. 0 que mais chama a atenção nessa passagem, entretanto, é a forma como ele conjuga elementos de uma cultura política secular, que se baseia numa análise crítica e racional dos fundamentos do poder, e, portanto prescindindo de argumentos teológicos, com uma leitura religiosa das leis naturais cuja autoria ele atribui a Deus. Nesta linha de raciocinio, o desrespeito aos direitos naturais, seria, antes de tudo, um desrespeito ao "Ente Supremo" que as fez em benefício dos homens. Esta conjugação de argumentos, a princípio, antagônicos, não deve ser estranhada se lembrarmos que vem de um padre político formado nos ensinamentos das luzes e da religião. Atitude também comum para um homem do século XIX que, como nenhum outro, soube conjugar com tanta originalidade fé e razão 28 . Por fim, apresenta-se como uma interessante estratégia de convencimento que, ao gosto do estilo retórico predominante então 29 , lança mão de dois argumentos de autoridade importantíssimos, quais sejam, a autoridade divina e a dos "filósofos de todas as eras".

Embora, de um modo geral, José Bento não explicite em quais filósofos ele se baseou para formular a sua teoria do Contrato Social, em uma certa passagem ele deixa claro um dos autores em que colheu determinadas idéias.

Em uma palavra, ser livre é não obedecer senão às leis. Um cidadão não exerce sua liberdade resistindo a uma legitima autoridade, torna-se insensato que rompe as barreiras destinadas a conservá-la. Todo cidadão, diz Locke, que destrói um governo 
30

O Pregoeiro Constitucional, N.2, p. 10, 11 de setembro de 1830 .

31

O Pregoeiro Constitucional, N. 23, p. 71, 24 de novembro de 1831.

32

Ibidem.

33

MOREL, Marco. As Transformações dos Espaços Públicos. Imprensa, Atores Políticos e Sociabilidades na Cidade Imperial. (1820-1840). São Paulo: HUCITEC, 2005. justo, se constitui cúmplice de sangue e males dos seus concidadãos. Todo o soberano que destrói as Leis, é um frenético que se expõe à licença dos cidadãos, que o mesmo há desenfreado 30 .

Desta passagem depreende-se que José Bento leu os dois "Tratados sobre o Governo Civil" onde Locke defende o direito fundamental à resistência e à insurreição. Curioso perceber, entretanto, a apropriação muito particular dada ao texto do filósofo inglês por nosso padre mineiro.

Seguindo um posicionamento muito coerente com sua condição de político liberal moderado, José Bento, em momento algum, remete à possibilidade do povo rebelar-se contra o soberano em caso de desrespeito às leis. Ao invés de enfatizar o direito à rebelião, ele chama a atenção para a necessidade do cidadão respeitar os governos legitimamente instituídos e, só timidamente, trata da crítica ao soberano que ignora as leis. Não que o objetivo maior do jornal não fosse o de denunciar os riscos que a Constituição sofria - como já vimos que o é -, mas, utilizar-se para isto de um trecho qualquer de Locke que legitime abertamente uma revolução seria perigoso demais no entendimento de José Bento. Além disto, as maiores denúnciass do jornal são voltadas, a princípio, aos cortesãos que cercam o imperador e envolvem-no com suas más influências. Neste momento, a pessoa de Dom Pedro I ainda não constituía um objeto explícito de críticas.

Uma outra observação importante a se fazer diz respeito ao entendimento da palavra povo nos discursos contratualistas d'O Pregoeiro. Quem seria esse povo responsável pela elaboração de um contrato com o governante? Em algumas passagens do jornal pode-se levantar algumas pistas.

\footnotetext{
Quando o homem procura levar-se por seus talentos e virtudes, nada mais natural, mais honesto e mais útil à causa pública, principalmente nos governos populares onde só os talentos e virtudes podem mover o Povo a conceder ao candidato a preferência que the ambiciona; porque o Povo não presta seus votos senão a homens que defendam seus direitos contra o poder... 31
}

Segundo o que escreveu José Bento, o Povo tem o poder de conceder votos, de onde se conclui que o Povo é constituído pelos segmentos votantes. Como no periodo em questão, o voto era censitário e indireto, portanto, bastante restritivo, conclui-se que o Povo do nosso padre político era formado por aqueles que possuiam renda suficiente para constituírem o seleto grupo dos votantes e eleitores brasileiros. Conseqüentemente, quando ele fala que soberano no Brasil é o Povo ${ }^{32}$, tem-se mais claro o entendimento de quem é, ou, no caso, deveria ser, o detentor desta soberania. Conforme colocado por Morel, as lógicas que estruturavam as divisões políticas fundamentais no Primeiro Reinado e regências expressavamse na tripartição de soberanias: a Soberania Monárquica, defendida pelo grupo conservador; a Soberania do Povo, valorizada pelos exaltados, sendo povo aqui tomado num sentido mais amplo que abarca as camadas pobres urbanas, livres ou libertas e, finalmente, a Soberania da Nação, defendida pelos moderados e representada pelos homens cultos e sábios que ocupam lugares na Assembléia Geral33. Embora utilize a palavra Povo para designar aquele que detém o poder soberano, está claro que José Bento defendia a Soberania da nação à maneira dos liberais moderados.

Retomando a análise da luta principal empreendida pelo periódico de Pouso Alegre, cabe destacar os outros recursos utilizados pelo editor d'O Pregoeiro em sua batalha contra os inimigos da Constituição, isto é, os 
34

O Pregoeiro Constitucional, N. 11, p. 45, 13 de outubro de 1830.

35

O Pregoeiro Constitucional, N. 50, p. 205, 12 de março de 1931.

36

O Pregoeiro Constitucional, N. 24, p. 99, 27 de novembro de 1830.

37

MENEZES. Lená Medeiros de. Civilização e Barbárie como mitos de combate: uma permanente revisitação. Revista Brasileira de História, São Paulo: ANPUH/Humanitas Publicações, no prelo.

38

O Pregoeiro Constitucional, N. 26, p.107, 4 de dezembro de 1830. "representantes do absolutismo".Qualquer ato de desrespeito à lei é tido por José Bento como atitude tirânica ou despótica. Esta, por sua vez, é sempre associada aos modelos de governo orientais, tidos como contra-exemplo daquele que seria o modelo ideal, qual seja, o americano.

Este lugar chamado Pátria não desperta no coração do muçulmano a mesma sensação que no do inglês, francês e americano: para aquele a pátria não é senão uma vasta quinta onde eles, a beneplácito do déspota, suportam uma penosa existência ${ }^{34}$.

\section{Em outra passagem}

Um governo que se não pode sustentar senão derramando rios de sangue humano e que não oferece à submissão e à desesperação senão uma cabeça que derribar, não é o mais imoral de todos? Pois tal é o despotismo Oriental ${ }^{35}$.

Na mesma linha de raciocínio, ele afirma que os membros do que chama partido recolonizador "são indignos de respirar o ar Americano e antes próprios para servirem ao sultão de Constantinopla"36. Utilizandose de um interessante recurso imagético, José Bento procura associar os intentos contra a Constituição às atitudes dos "sanguinários" orientais, alertando seus leitores para o risco do Brasil se perder nos caminhos da tirania. A partir de uma leitura transversal é possivel perceber que o padre político joga com dois conceitos que, de certo modo, existem em função um do outro: o de civilização e o de barbárie ${ }^{37}$. Sabe-se que em vários momentos de crise politica, travam-se lutas simbólicas que recuperam, sob novas formas, a oposição básica entre o bem e o mal, essência das grandes religiões, desdobrada em novos confrontos. Deste modo, não foram poucas as vezes que o oriental não cristão teve sua figura aproximada à do bárbaro, do mal e do tirano. Partindo de um sistema de representação já introjetado - bem e mal, civilização e barbárie, oriente e ocidente - fica mais fácil para editor d'0 Pregoeiro, realizar a associação absolutismo $=$ oriente $=$ barbárie e, conseqüentemente, incitar em seus leitores o desejado sentimento de defesa dos valores liberais.

Se o absolutismo estaria para o oriente, qual sistema de governo estaria para a América? José Bento escreve que

Todas as idéias de paz, justiça e virtude se encerram em uma palavra: o bem geral. Considerados debaixo deste ponto de vista os governos não são senão de duas maneiras, que se encaminhem, que se desviem do bem geral: os primeiros são os Republicanos ou justos; como se quiser entender, porque o bem geral, a justiça, a coisa pública é uma e mesma coisa. Quanto aos outros são injustos e despóticos ${ }^{38}$.

Esta passagem exige uma cuidadosa leitura da palavra república tendo em vista não só a polissemia dos conceitos engendrados por ela, como a possibilidade do uso, proposital, das suas várias acepções de forma concomitante. No caso da citação acima, entende-se que república foi utilizada no sentido clássico do direito romano, isto é, como coisa pública, como organização de um Estado que visa, tal como coloca José Bento, "o bem geral". Esta interpretação é reforçada por outra passagem onde o redator toma 0 cuidado de deixar claro que não entende republicanismo como sinônimo de governo eletivo temporário, tal como o adotado no restante da América.

Qual será o motivo porque tais escritores tanto forcejam por esmagar o Republicanismo, quando inteiramente perdem de vista o absolutismo? Não sabem que nossa Constituição bem observada está para essa forma de governo, como mal observada 
BARBOSA, Silvana. A Soberania Monárquica e a Soberania Popular em Bernardo Pereira de Vasconcelos. Anais XIV Encontro Regional de História da ANPUH-MG/Juiz de Fora, Julho de 2004.

41

0 Pregoeiro Constitucional, N. 26, p.107, 4 de dezembro de 1830

42

0 Pregoeiro Constitucional, N.2, p.8, 11 de setembro de 1830. fica para o absolutismo? ....eles bem conhecem que o nosso governo bem pouco difere dos demais da América, com a exceção de termos um chefe vitalício 39 .

Uma vez colocado que a nossa Constituição permite uma forma de governo republicana, entende-se que república é tratada aqui como sinônimo de constitucionalismo (monárquico ou não). 0 respeito às leis instituidas por meio do contrato social seria o grande elemento em comum existente entre a "república brasileira" e as demais repúblicas do continente americano. Curioso notar, entretanto, que por inúmeras vezes o editor d'0 Pregoeiro fez referência ou transcreveu artigos de jornais exaltados - tais como 0 Republico e Nova Luz Brasileira -que, naquele momento de crise do Primeiro Reinado, utilizavam, circunstancialmente e de forma sutil e insinuada, a palavra república com a conotação de governo eletivo temporário. Resta saber se a referência a estes jornais refletia por parte de José Bento um entendimento do termo república diferente do intencionado pelos redatores exaltados - não compreendendo as suas sutilezas - ou se, na verdade, representava somente uma aliança temporária contra um inimigo comum - os excessos do poder Executivo e do Moderador - a despeito dos seus divergentes projetos políticos.

Diante do exposto até então, pôde-se perceber que, em consonância com o posicionamento político daqueles que gravitavam em torno de Feijó, José Bento iniciou uma campanha em favor do sistema constitucional. Aliás, é preciso dizer que o constitucionalismo expressava uma doutrina muito comum aos deputados que colocavam na Constituição todas as esperanças para a consolidação do Império. Nas palavras de Silvana Barbosa, tal doutrina, "resume a posição de boa parte dos políticos imperiais naqueles anos, quando todos se tornaram fiéis defensores da Constituição do Império do Brasil, pois seguir a Constituição seria a única forma de manter a liberdade de um povo".40 Ser constitucional, por sua vez, apresentava-se para grande parte da elite política da época, como sinônimo de moderação e bom senso. Não por acaso, a defesa dessa doutrina foi feita por José Bento sem que esse se descuidasse de manter um discurso equilibrado, ou, como bem gostavam dizer os partidários da moderação, baseado no "justo meio". Solicitando prudência a seus leitores, escreve:

Muitas vezes querendo-se evitar um vício cai-se em outro: uma violenta agitação está tão próxima da discórdia como uma funda paz e muitas vezes a paz dos túmulos - o bem fica entre os extremos ${ }^{41}$

\section{3- 0 Pregoeiro das reformas}

A noção de onde se encontra o justo meio, entretanto, pode transformar-se à medida que mudam os contextos políticos. Nos primeiros meses de sua publicação, o justo meio para 0 Pregoeiro Constitucional encontrava-se na defesa da Constituição brasileira "onde são proclamados os mais santos principios, a igualdade, a liberdade de pensar, a segurança do individuo, a instrução pública, a abolição das penas bárbaras" políticas que marcaram os primeiros meses de 1831 e, em particular, a demissão do gabinete do marquês de Barbacena fizeram com que o editor d'O Pregoeiro perdesse parte de sua moderação e assumisse um tom mais agressivo em relação, não só ao círculo palaciano, como também, ao próprio Dom Pedro I. 0 justo meio estaria, agora, na defesa da reforma da Constituição, visto que, diante dos novos acontecimentos, esta já não se mostrava 
43

O Pregoeiro Constitucional, N.60, p.250, 20 de abril de 1831.

\section{4}

O Pregoeiro Constitucional, N. 40, p. 163, 5 de fevereiro de 1831.

45

Ibidem.

\section{6}

Ibidem.

\section{7}

O Pregoeiro Constitucional, N.62, p.257, 27 de abril de 1831.

48

O Pregoeiro Constitucional, N. 54, p.220, 30 de março de 1831. tão intocável assim. Apresentado-se como um representante dos desejos do povo brasileiro, escreve 0 Pregoeiro:

0 que pretendem os brasileiros? Reforma da Constituição. De que necessitam os brasileiros? De reforma da Constituição. 0 que pode salvar os brasileiros da opressão e aviltamento em que jazem e dos males de que sobre eles pesam? Reforma da Constituição 43 .

Entretanto, temendo que os corcundas se aproveitassem dos pedidos de reforma da Constituição para atacar a todo o sistema constitucional e, conseqüentemente, conseguindo "convencer alguns incautos de que eles tinham razão de falarem contra o sistema44", o editor esclarece que:

Quando se diz que é necessário reformular a Constituição, não se quer dizer que ela é toda má; pelo contrário, os mesmos que recomendam a reforma confessam que a maior parte dela é ótima, que é nessa parte que ela tem feito, faz e fará a ventura do Brasil. (...) A reforma, pois deve recair sobre uma pequena parte do sistema.... 45

Do mesmo modo, José Bento alerta seus leitores de que, ao contrário do que alardeavam os corcundas, uma reforma constitucional não requer nenhuma revolução - aqui entendida em sentido negativo, vinculado aos horrores da Revolução Francesa - visto que a mesma encontra-se prevista na própria Constituição.

\footnotetext{
...nem penseis que será necessária essa revolução, como ameaçais aos tímidos: porque um povo livre apenas conhece a necessidade de uma reforma, prontamente acede a ela, muito principalmente sendo autorizada pelo Código Fundamental ${ }^{46}$.
}

Uma atitude muito curiosa de José Bento, contudo, merece aqui um aparte. Nos dias imediatamente posteriores ao ato de abdicação de Dom Pedro I (e um dia depois da publicação de sua abdicação pelo 0 Pregoeiro), quando os liberais moderados puderam, ainda que por pouco tempo, respirar aliviados e mais seguros em relação à ameaça absolutista dos corcundas, o nosso padre político sentiu-se mais tranqüilo em mostrar publicamente o que achava, realmente, da Constituição outorgada em 1824.

Tínhamos uma Constituição, é verdade, mas de frivolo pretexto porque, pouco liberal, esta só servia para disfarce de escandalosas ações de almas danadas, esta só servia de escudo da maldade contra o tiro da justiça 47 .

0 que antes era tratado como responsável pela "ventura do Brasil", agora, é tomado como "disfarce escandaloso". 0 mais interessante é que, ao referir-se à Constituição no passado, o padre já tinha como certa a sua tão desejada reforma.

Retomando, contudo, aos discursos travados antes do 7 de abril, vale também observar como 0 Pregoeiro, assim como os demais jornais oposicionistas de Dom Pedro I, lançaram mão da idéia de um complô que estaria sendo elaborado por um "Gabinete Secreto" (composto pelo círculo intimo do imperador) como um poderoso instrumento de combate. A fim de alardear a necessidade de reformar o mais rápido possivel a Constituição dizia-se que"o gabinete secreto e o governo da boa vista continuam em suas manobras; se os periódicos perderem de vista estes dois inimigos da liberdade, adeus liberdade".48Se havia uma conspiração sendo tramada pelo "Gabinete secreto", qual seria, pois, o seu objetivo? Nas palavras de José 
49

O Pregoeiro Constitucional, N. 35, p.145, 15 de janeiro de 1831.

\section{0}

GIRARDET, Raoul. Mitos e Mitologias Politicas. São Paulo: Companhia das Letras, 1987.

51

O Pregoeiro Constitucional, N. 60, p.250, 20 de abril de 1831.

\section{2}

Art. 13. 0 poder legislativo é delegado à assembléia geral, com a sanção do imperador. Art. 62. Se qualquer das duas câmaras, concluída a discussão, adotar inteiramente o projeto que a outra câmara Ihe enviou, o reduzirá a decreto, e depois de lido em sessão, o dirigirá ao imperador em dois autógrafos, assinados pelo presidente e os dois primeiros secretários, pedindo-Ihe a sua sanção pela fórmula seguinte: "Assembléia geral dirige ao imperador do decreto incluso, que julga vantajoso e útil ao império, e pede a SMI se digne dar a sua sanção". Constituição Política do Império do Brasil.

53

O Pregoeiro Constitucional, N.52, p.213, 23 de março de 1831.

54

O Pregoeiro Constitucional, N.52, p.213, 23 de março de 1831.
Bento seria "fazer retrogradar a causa liberal, a causa da pátria, a causa da América ${ }^{49 "}$. Em outras palavras, restaurar o absolutismo.

0 recurso mítico como estratégica de convencimento, surge, em geral, em momentos de angústia e contestação. 0 tema da conspiração, tal como apresentado pela imprensa brasileira no contexto em questão, é colocado sob uma simbólica de mácula, do segredo e desejo de dominação. Girardet50lembra, entretanto, que todas essas construções míticas são interpretadas como uma resposta à ameaça ou como uma reação quase instintiva à ameaça, sendo que pouco importa a exata medida da realidade dessa última.

Reformar a Constituição mostrava-se, assim, como uma necessidade premente. Interessa, agora, compreender o teor de tal reforma;

E como e quando querem os brasileiros a reforma constitucional? Federando-se as províncias e já, e suprimindo ou adicionando uns artigos da Constituição e alterando-se outros, bem como o 13, 62 e seguintes, parte do Tit. 5 e outros mais que a sabedoria das câmaras legislativas mui bem conhece. ${ }^{51}$

Os dois artigos constitucionais acima citados tratam do poder Legislativo e do modo como este se encontra dependente das sanções do imperador ${ }^{52}$. Já o Título $V$ refere-se às atribuições do imperador, dentre as quais a de exercer o Poder Executivo e o Moderador. A proposta de reforma desses artigos e das atribuições do imperador significa, na verdade, o desejo de reforçar o caráter liberal da Constituição, diminuindo a força do poder executivo e do poder moderador (ou extinguindo-o) e, conseqüentemente, ampliando o poder do legislativo, numa prevalência da Soberania Nacional em relação à Soberania Monárquica. Em outras palavras, visava-se corrigir a relação assimétrica entre o poder do imperador ( Executivo e Moderador) e a Câmara dos Deputados, distorção esta que minava o caráter liberal da Constituição. 0 outro ponto levantado pela proposta da reforma constitucional dizia respeito à implantação do modelo federativo. Este, antes mesmo da abdicação de Dom Pedro I, mostrou-se presente nos discursos de José Bento.

É de suma importância notar que a possibilidade já vista neste trabalho de uma palavra, tal como Federalismo, conter vários significados não causa confusão somente aos historiadores que se debruçam sobre os escritos do século XIX. Os próprios contemporâneos aos textos aqui analisados confundiam-se diante de tantos novos conceitos ou de novas acepções atribuídas a velhos conceitos, quando não, atribuídas de forma simultânea aos velhos sentidos. Essa confusão é bem retratada por um assinante $d^{\prime} 0$ Pregoeiro que, por meio de uma carta enviada ao jornal, roga aflitivamente ao editor que explique com clareza o que entende por sistema federativo para que, então, ele possa se desfazer "de certa suspeita...". A confusão, explica o assinante, vem da leitura de várias folhas da Corte que, ao tratarem do tal sistema, "entendem cada um a seu modo".53 Na carta transcrita inteiramente pelo jornal, o assinante explica qual seria a confusão e que tipo de suspeita alimentava:

Falemos com franqueza, V.M. e os redatores de outras folhas federalistas querem uma República no Brasil; mas eu penso que tal espécie de governo não convém ainda. Se não é república o que V. Mces querem, se é antes a mesma Constituição reformada e se esta reforma é vantajosa ao nosso Brasil, porque razão os outros periódicos liberais, que desejam igualmente o bem do Brasil, não subscrevem a mesma doutrina, antes a rebatem? 54 
55

O Pregoeiro Constitucional, N.52, p.213, 23 de março de 1831.

56

O Pregoeiro Constitucional, N. 71, p.293, 28 de maio de 1831.

57

Ibidem.
A grande questão do assinante era saber se o modelo federativo encontrava-se necessariamente vinculado ao sistema republicano. Em resposta à solicitação do assinante, José Bento desenvolve um texto onde explica o sentido e a extensão da sua proposta federativa.

Confederação ou como quiserem chamar, sistema federativo nada mais é do que uma sociedade comum. É da essência desta sociedade que os Estados que a formam conservem cada um a sua soberania.(....) Em conseqüência de se conservarem soberanos, eles ficam independentes e, como tais, Sr.s de se governarem cada um da maneira que quiserem (...). 0 modo de se constituirem os Estados em uma sociedade Federativa é o mesmo que se observa na organização de um só Estado. Reúnem-se as forças e vontades, cujo complexo vem a ser a soberania geral dos estados. Forma-se a Lei, ou Pacto Fundamental, onde se marca o modo porque os Estados devem ser governados. ${ }^{5}$.

Dessa citação depreende-se por federação um governo no qual muitos estados formam uma só nação e onde cada um pode cuidar de sua legislação que, é, entretanto, limitada por uma Constituição Geral. Mais interessante, contudo, é que, em uma publicação posterior, José Bento faz referência ao que seria uma federação democrática, mais próxima do modelo norte americano:

Eis cada província cuidando em seus próprios interesses sem dependência de um corpo legislativo e de um governo colocado a tantas léguas de distância: eis cada uma podendo nomear seus presidentes e demais autoridades e, por conseguinte, livres da contingência de serem governados por homens sem opinião pública e sem outros dados necessários para bem governar ${ }^{56}$.

Chama-nos a atenção esta passagem tendo em vista que, nem mesmo entre os liberais exaltados havia um consenso acerca do modelo federativo a ser adotado no Brasil, isto é, se o democrático, tal como proposto pelo padre político d'0 Pregoeiro, ou se o chamado monárquico, cuja nomeação dos administradores da província viria do governo central.

A intrigante opção federalista democrática de José Bento, não pode, todavia, ser confundida com republicanismo. Na mesma reposta à carta do assinante ele faz questão de eliminar qualquer resquício dessa suspeita:

Parece-nos que desejar isto (o sistema federativo) não é querer uma República no Brasil, nem coisa que se oponha à essência do nosso sistema jurado. (...) Não somos republicanos como supõe e o sistema federativo na acepção em que tomamos em si é bom ... 57

0 curioso desta passagem é que nela José Bento atribui à palavra República um sentido bem diferente daquele dado por ele poucos meses antes dessa publicação. Agora, república passa a ser entendida como governo eletivo temporal - posto que se opõe " a essência do nosso sistema jurado" - e não mais como sinônimo de governo das Leis. Essa mudança de compreensão semântica reflete, com certeza, as transformações do contexto, isto é, a radicalização da crise do governo de Dom Pedro I, o que poderia ser uma brecha para a implantação do republicanismo proposto por parte dos exaltados.

0 editor d'O Pregoeiro justifica a necessidade da federação tendo em vista o tamanho do território brasileiro e de suas particularidades regionais. Em um governo centralizado, "o recurso ao congresso e ao poder executivo torna-se muito dificil e demorado, de maneira que quando chegam 
58

0 Pregoeiro Constitucional, N. 71, p.293, 28 de maio de 1831

59

Ibidem.

60

0 Pregoeiro Constitucional, N.66, p.276, 11 de maio de 1831.

61

O Pregoeiro Constitucional, N. 71, p.293, 28 de maio de 1831.

62

O Pregoeiro Constitucional. Edição Extraordinária, p.2, 21 de março de 1831.

63

O Pregoeiro Constitucional, N. 67, p.279, 14 de maio de 1831.

64

O Pregoeiro Constitucional, N.22., p.91, 20 de novembro de 1830.

65

Ibidem. as providências reclamadas, o mal já não tem remédio, as circunstâncias estão mudadas".58 Dentro do mesmo raciocínio segue alegando a necessidade das provincias serem governadas por homens que conheçam suas características, pois, "o congresso geral nunca pode ser composto de homens que além dos conhecimentos locais de suas respectivas provincias, estejam bem ao fato das necessidades peculiares daquelas onde eles não residem".59Por último e como mais importante argumento, alega que com a federação, as rendas das províncias seriam melhor utilizadas do que se administradas pelo governo geral, acostumado à ostentação da Corte.

Vale assinalar que a defesa da autonomia das províncias é, estrategicamente, conjugada por José Bento com o discurso de união, ou, em outras palavras, como estratégia de manutenção da unidade nacional (que não se confunde com governo unitário). Com a federação ele vê "as províncias estreitando mais os laços de fraternidade, socorrendo as mais poderosas e mais ricas às mais fracas e mais pobres porque sabem que a felicidade do todo depende da felicidade das partes".60 Também, a adoção do sistema federativo seria uma das maneiras de se evitar a repentina separação das províncias, posto que se vivia num momento em que "os espiritos conservavam, ou antes, aumentam a eletricidade desenvolvida pelo choque da revolução: época em que a confiança no governo ainda vacila"61. Com esse mesmo tipo de discurso, ele procura afastar o medo que a palavra federação podia causar: "essa palavra tão doce - Federação - não oferece mais que a idéia de união e fraternidade entre os brasileiros para repelir os embates do poder e firmar a segurança das provincias".62

Como visto até agora, 0 Pregoeiro Constitucional tomou para si duas grandes causas. Em um primeiro momento, ele apresentou-se como o defensor da Constituição; posteriormente, tornou-se um grande pregoeiro da reforma constitucional. Porém, simultaneamente a essas discussões centrais, outros temas, ainda que de forma esporádica e marginal, foram tratados por José Bento. Iremos nos ater somente a dois deles.

A escravidão é o primeiro desses temas. Em diferentes momentos, 0 Pregoeiro denunciou o pouco interesse da Assembléia Geral em resolver o problema da emancipação dos escravos. Mesmo sabendo que "a escravidão é contrária à religião de Jesus Cristo e à humanidade", 63 haveria sempre uma indisposição em relação a qualquer medida que tratasse da escravidão, reclama José Bento. Este assunto, ele diz, "não passando de meros motivos a belíssimas reflexões e teorias, não tem, entretanto, merecido aquele desvelo que se Ihe deve".64Em seguida, utilizando-se da noção de direitos naturais, afirma que "todos sabem que não há razão, nem princípio algum fundado no Direito da Natureza que favoreça semelhante violência". 65 Interessante notar que em um artigo anterior a este, nesta mesma edição, José Bento, lançando mão da crença nos direitos naturais, redigiu um extenso texto em defesa do direito de propriedade e de como este é plenamente defendido pela Constituição. Este artigo vem corroborar a compreensão de que, para este padre político, o direito natural à vida sobrepõe-se ao direito natural à propriedade quando, neste caso, a propriedade é o escravo. Todavia, não há nenhuma menção ou proposta concreta no jornal de como e quando se daria o processo de abolição.

0 segundo tema abordado pelo jornal e por nós retratado referese, como não poderia deixar de ser, às questões eclesiásticas. 0 clero, no entender desse padre político teria, assim como os periódicos livres, a importante missão de disseminar as luzes. Retrucando àqueles que argu- 
66

O Pregoeiro Constitucional, N. 25, p.101, 1 de dezembro de 1830

67

Ibidem.

68

Ibidem.

69

Ibidem.

70

O Pregoeiro Constitucional, N. 55, p.224, 2 de abril de 1831.

71

Ibidem.

72

O Pregoeiro Constitucional, N. 72, p.295, 4 de junho de 1831. mentam que a natureza da função eclesiástica não permitia este tipo de atividade, José Bento alega ser a própria religião católica que exige a bondade do homem, o que, necessariamente, estaria vinculado ao conhecimento dos seus direitos e deveres. Portanto, "convém, pois que os ministros da lgreja, desde os prelados até os párocos se aproveitem do poderoso ascendente que ainda exercem sobre suas ovelhas (...) inspirando-Ihes amor às novas instituições".66 Na verdade, o que esse padre politico espera é que seus irmãos de batina tornem-se verdadeiros pregoeiros das idéias liberais. Quão depressa, escreve ele "a civilização se dilataria por todas as classes, se os curas da alma tomassem o trabalho de preparar os ânimos para recebê-la já em suas práticas, mesmo no confessionário, por uma conduta decididamente liberal?".67 0 grande obstáculo à adoção da civilização ou das idéias liberais por parte do clero seriam os bispos, condescendentes com as ordens religiosas "abuso igualmente prejudicial ao Estado e à religião".68 Vale lembrar que os bispos, de um modo geral, tenderam a assumir uma postura mais conservadora, tanto no que se refere às questões de ordem política quanto às ligadas diretamente à Igreja, se é que podemos tratálas assim, separadamente. Sabendo disto é que José Bento declara serem os bispos "os mais inimigos da perfeição social" voltando seus apelos, portanto, "principalmente aos párocos atuais que não esperam o exemplo dos prelados para cumprirem os deveres que Ihes impõem o seu cargo; a eles é que rogamos em nome da sociedade, a quem devemos servir como cidadãos e empregados públicos".69Eis aqui uma atitude perfeitamente coerente para um padre político - e, portanto, defensor da atuação política do clero - bem como, um modelo de discurso típico de um católico liberal.

\section{4- 0 padre, a Constituição e o Golpe de Estado.}

No dia 4 de junho de 1831 foi publicado o último número d'O Pregoeiro Constitucional. Nessa edição não há nenhuma despedida, agradecimento aos leitores ou explicação para o encerramento das atividades do jornal, o que nos leva a crer que esse fato não tenha se dado de forma premeditada. É plausivel pensar que o deputado José Bento, diante da abdicação de Dom Pedro I, precisava mais do que nunca, fincar presença na Corte de modo a garantir que seus projetos políticos não se perdessem em meio à confusão instaurada com a ausência do imperador.

Porém, antes de encerrar temporariamente as suas atividades jornalisticas em Pouso Alegre, José Bento tomou o cuidado de levar ao sul de Minas, ainda que com alguns bons dias de atraso (a notícia da abdicação de Dom Pedro I só chegou em 26 de abril) todas as informações referentes à movimentação política que levaria o imperador à abdicação. Também ele, por meio de seu jornal, incentivou o povo mineiro a se juntar aos "soldados da pátria". Remetendo-se ao governo, o padre político não se cansava de avisar que "todos se armam nas vilas e nas próprias roças para a defesa da pátria, da Constituição e da independência nacional e que estão decididos a morrer antes do que ser escravos ${ }^{70 ",}$ terminado, vários de seus escritos com a seguinte conclamação: "Mineiros, contai com todo o Brasil, o Brasil conta convosco".71

Após a "gloriosa revolução operada no Rio de Janeiro"72 em 7 de abril de 1831, impunha-se a necessidade de concretizar as reformas constitucionais. Todavia, diante dos obstáculos impostos pelo Senado à aprovação das propostas encaminhadas pelos deputados, José Bento juntou-se a outros padres e políticos para planejar o fracassado golpe de 30 de junho de 1832 
Sobre o golpe, ver: SOUSA, Octávio Tarquínio de. Tentativa de Golpe de Estado de 30 de julho de 1832. (A Revolução dos Três padres). IN: História dos Fundadores do Império do Brasil. V. 8. Belo Horizonte: Itatiaia/São Paulo: EDIUSP 1988.; CASTRO, Paulo Pereira de. A Experiência Republicana, 1831-1840. In: HOLANDA, Sérgio Buarque de. História Geral da Civilização Brasileira. T. II-0 Brasil Monárquico, Vol.II. São Paulo: Difusão Européia do Livro.

MOREL, Marco; BARROS, Mariana Monteiro de. Palavra, Imagem e Poder. 0 surgimento da imprensa no Brasil do século XIX. Rio de Janeiro: DP\&A, 2003. p.7. que visava, dentre outras coisas, conseguir a aprovação da Constituição de Pouso Alegre pela Assembléia Geral, transformada em Constituinte ${ }^{73}$.

Editada na oficina d'O Pregoeiro Constitucional, a Constituição de Pouso Alegre sistematizava muitas das propostas que, durante quase um ano, aquele jornal ajudou a difundir, tais como o fim do poder moderador, a abolição da vitaliciedade do senado e a criação das Assembléias Provinciais. Não constava desta Constituição, entretanto, o sistema federalista democrático, tal como defendeu José Bento pouco mais de um ano atrás n'O Pregoeiro. Também não havia nenhuma referência à situação do trabalho servil. Não sabemos, contudo, até que ponto o nosso padre político ajudou na elaboração dessa carta constitucional. Se houve, de fato, uma participação direta de José Bento, não saberíamos dizer se, por exemplo, seu modelo federalista democrático foi voto vencido ou se, realmente, passado o calor das lutas contra Dom Pedro I, ele achou por bem assumir uma postura mais moderada, recuando em alguns de seus projetos. Essas questões alimentam as dúvidas em relação ao grau de homogeneidade existente não só entre os padres promotores do golpe, como entre os católicos liberais como um todo, e reforçam a idéia de que seus projetos políticos não se encontravam ainda consolidados, mas, ao contrário, sofriam consideráveis transformações.

Transformações, aliás, parecem ter sido a marca maior desses anos de instabilidade política transcorridos entre a independência do Brasil e o término do Período Regencial. Transformações nos conceitos, que surgiam ou que ganhavam novos significados, muitas vezes, sem abolir completamente a antiga semântica. Transformações nos agrupamentos políticos, ensaiando futuros partidos. Conseqüentemente, transformação nos projetos políticos que ganhavam consistência ou que se reformulavam diante da realidade da tomada do poder. Transformações estas que refletem o descobrimento da política e de suas engrenagens por parte dos brasileiros.

Neste processo de aprendizado e experimentação política, periódicos como 0 Pregoeiro Constitucional foram, sem dúvida, um dos mais importantes laboratórios. Esta constatação é corroborada pela afirmação de Morel de que "a imprensa e a nação brasileira são praticamente simultâneas". ${ }^{74}$
Recebido para publicação em fevereiro de 2007

Aprovado em fevereiro de 2007 